\title{
Relationship of iron ore price with other major commodity prices
}

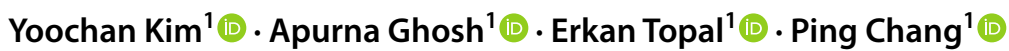

Received: 16 June 2021 / Accepted: 17 January 2022 / Published online: 31 January 2022

(c) The Author(s) 2022

\begin{abstract}
Understanding the interdependency of commodity market pricing system is very important for running a successful mining business. Much of the iron ore price is derived from the prices of other commodities. This study investigates the relationship between monthly iron ore prices against 12 other monthly commodity prices or indices including LNG, aluminium, nickel, silver, Australian coal, zinc, gold, oil, tin, copper, lead, and Commodity Price Index (Metals) in both bivariate and multivariate perspectives. An augmented Dickey-Fuller (ADF) test is carried out to ensure that all the time series commodity prices and index are non-stationary. In multivariate modelling co-integration tests, observation is made on how many co-integrations exist out of 12 co-integrations for each respective lag between 0 and 45 months' period. It is observed that 6 out of 12 commodity prices follow co-integrations in 1-month lag and continues in a cyclic pattern until 27 months after which it disappears. There are 3 commodities which continuously co-integrate with iron ore price change at all lags. For bivariate modelling, vector error correction model (VECM) estimation is carried out to prove the evidence of short-run responses to long-term relationship between iron ore prices and it is observed that oil, copper, and Australian coal prices have influence on and from iron ore prices. Then, Granger causality test is carried out to verify the VECM result by testing bi-directional causality between iron ore prices and copper, oil, and coal prices. It has been concluded that the iron ore price has bi-directional influence on oil, copper, and Australian coal prices and vice versa.
\end{abstract}

Keywords Iron ore price $\cdot$ Major commodity prices $\cdot$ Vector error correction model $\cdot$ Johansen co-integration $\cdot$ Granger causality

\section{Introduction}

Mining is a capital-intensive industry that requires hundreds of million-dollar investment in major equipment (Fu et al., 2014), as well as continuous operational and capital expenditure. Investments in the mining and minerals industry are regarded risky (Topal, 2008). Each mining project is highly

Apurna Ghosh

Apurna.Ghosh@curtin.edu.au

Yoochan Kim

yoochan.kim@postgrad.curtin.edu.au

Erkan Topal

E.Topal@curtin.edu.au

Ping Chang

ping.chang@curtin.edu.au

1 Department of Mining Engineering and Metallurgical Engineering, Western Australian School of Mines, Curtin University, Locked Bag 30, Kalgoorlie, WA 6433, Australia sensitive to commodity price and there is some turbulence in commodity prices in recent years.

Iron ore is a highly important mineral for the human civilization as it is used to produce steel. Vast majority of world production (56\%) and export (74\%) is heavily reliant to Australia and Brazil, and China is the single largest importer with $66 \%$ of world iron ore import, meaning diversity of seller and buyer is limited (OEC - Iron Ore 2021). With declining relationship between Australia and China over past few years, importance of iron ore has emerged as a key commodity surrounding tensions of both countries because the Australian economy is heavily dependent on iron ore exports and Chinese heavy industry is equally reliant on low-cost Australian supplies (Wilson, 2017).

Historically, iron ore was traded on long-term basis contracts. However, since 2006, there has been a change to annual negotiation system between large producers and large consumers and subsequently spot market trades based on prices set by independent benchmarking companies which consequently have seen rapid fluctuation of 
iron ore prices (Caputo et al., 2013). Iron ore price fluctuated between US $\$ 40$ to almost US $\$ 190 /$ tonne in the past two decades (Market Index Iron Ore, n.d.). The forecast of iron ore price trend is vital for its producers and investors to be able to prepare for dramatic price changes in both short and long terms. The fall of iron ore price results in decreasing ultimate pit limit (UPL) as well as net present value (NPV) of mines, which in turn heavily affects the operational income of iron ore mines. Hence, it is essential to evaluate the potential causes of the change in iron ore price so that it can eventually be captured in tools to forecast short-term (ST) and long-term (LT) iron ore prices for managing the targeted production. In order to forecast the iron ore price, the first step is to understand and analyse the possible relationship of iron ore price with other potential variables.

Several studies have been done to understand the relationship between iron ore price and other economic index as well as other commodity prices. Pustov et al. (2013) modelled long-term iron ore price using marginal costs (future lows) and marginal incentive price (future highs) and forecasted as $\$ 85 /$ tonne and $\$ 124 /$ tonne respectively considering depletion of existing iron ore deposits and targeted return on investments for new projects. Haque et al. (2016) determined that when the iron ore price increases, Australian dollars also increase but no influence occurs the other way around. Warell (2018) found out that the iron ore price, GDP growth in China, and freight rates were co-integrated in the long run. The structural break test was used to conclude that the change in pricing regime does not have a significant impact on the iron ore price when extending the time period; however, the most important factor for iron ore prices up to 2012 was GDP growth in China. Ma and Wang (2019) expanded the finding that oil, gas, coal, and iron ore prices are all associated with an increase in appreciation of Australian dollars and a decline in the Chinese RMB.

Big mining companies often produce different commodities of diverse portfolio and yet no study has been explored on the interactions of different commodity prices. It will be beneficial for mining companies and investors to find out the relationship between different commodity prices so that change in iron ore price can be predicted not only for maximizing the profit but also for risk mitigation purpose.

In this paper, twelve prices on LNG, aluminium, nickel, silver, Australian coal, zinc, gold, oil, tin, copper, lead, and Commodity Price Index for Metals (CPI) have been studied against iron ore price. Twelve commodity prices are readily available and cover the diverse portfolio of different mining companies. LNG, oil, and coal price is studied against iron ore prices as these are fuel to run the industry and civilization. Other minerals such as aluminium, copper, nickel, zinc, tin, and lead are also studied as they all serve similar purpose to steel which is the end use of iron ore. All the minerals above are essentially used in our civilization especially in different industries, infrastructure, manufacturing, as well as construction, economic climate, as well as market risk profile. The reason why gold and silver are studied is because gold and silver prices are the key indicator for economic climate as well as market risk profile.

The objectives of this paper are to (1) find out the bivariate and multivariate co-integrating relationship of monthly iron ore prices with 12 other monthly commodity prices or indices by employing the Johansen cointegration test and (2) reveal the short-run responses to long-term relationship between iron ore prices and 12 different commodity prices over the period from 1990 to 2020 through the vector error correction model (VECM) and Granger causality test.

\section{Research method}

\section{Sources of data-commodity prices and index}

In this paper, monthly iron ore prices over the period from 1990 to 2020 are considered which include pre- and posttransition period when iron ore prices change to shorterterm pricing and subsequently spot market trades (Caputo et al., 2013). There will be input variables which will be considered to test co-integration with iron ore price. These input commodity prices are CPI, gold, oil, silver, LNG, aluminium, copper, tin, lead, nickel, zinc, and Australian coal. The monthly iron ore prices and all other metals and energy prices and indices were collected from Indexmundi (Market Index Iron Ore, n.d.). For all the econometrical and statistical tests, MATLAB software (MATLAB version, 2020) has been used.

\section{Necessity of unit root test-augmented Dickey-Fuller (ADF) test}

Economists often use unit root tests to determine whether the time series data of major economic indices are stationary or not. The Dickey-Fuller test (Dickey \& Fuller, 1979) has been performed in this study using Microsoft Excel Data Analysis Tool software to determine whether the time series variables contain a unit root or not to investigate the relationship between iron ore prices and all other variables using the Johansen co-integration test later in this research. This is because the co-integration test is applicable when the variables contain unit roots. Unit root is a stochastic 
trend in a time series, sometimes called a "random walk with drift." If a time series has a unit root, it shows a systematic pattern that is unpredictable. Typical unit root test formula (Johansen, 1991) is written as:

$\mathrm{Xt}=\mathrm{Dt}+\mathrm{Zt}+\varepsilon \mathrm{t}$

Testing the stationarity of a time series is performed in autoregressive (AR) model, which is a stochastic process model to capture interdependencies amongst multiple time series variables and is written as:

$\mathrm{X}(\mathrm{t})=\Phi \mathrm{X}(\mathrm{t}-1)+\cdots+\Phi \mathrm{X}(\mathrm{t}-\mathrm{p})+\varepsilon \mathrm{t}$

where $\mathrm{X}(\mathrm{t})$ is the time series variable (iron ore price history and other variables), $\mathrm{D}(\mathrm{t})$ is the deterministic component (or signal) that can be modelled through the modelling techniques, $\mathrm{Z}(\mathrm{t})$ is the stochastic component (a random probability distribution or pattern that may be analysed statistically but may not be predicted precisely), $\delta$ is the stationary error, $\mathrm{et}$ is the stochastic disturbances (or error terms), and $\Phi$ is the $\mathrm{k} \times \mathrm{k}$ matrix.

Each component will have its own outcome value and the null hypothesis is that there is a unit $\operatorname{root}(\delta=0)$. If unit root exists, $\Phi=1$ and would be non-stationary and if no unit root exists, $\Phi \neq 1$ it would be stationary. There are 3 test models randomly tested as part of the ADF test in this research, autoregressive (AR), autoregressive with drift variant (ARD), and trend stationary (TS). The null test models are tested against the alternative models.

The null hypothesis of the augmented Dickey-Fuller test is "The variable contains a unit root and is hence nonstationary" and the outcome is interpreted that if $p>0.05$, null hypothesis cannot be rejected, contains unit root, and is non-stationary and if $p<0.05$, null hypothesis is rejected, does not contain unit root, and is stationary.

\section{Johansen co-integration test}

To investigate the short-term or long-term (LT) relationship between iron ore price against several input variables, cointegration tests are required. Co-integration tests offer a basic outline of the data enabling estimation and interpretation of the variables given that the sequence of random variables is not stationary. The co-integration test provides an effective framework for testing models and estimate longrun relationships amongst co-integrated variables from the time series data.

The relationship between co-integration and error correction model was introduced by Granger (Granger, 1981) and is further developed by Granger and Weiss (Granger and Weiss 1983) who outlined the fundamentals of cointegration that if each vector of time series variable $\mathrm{X}(\mathrm{t})$ first reaching stationary after differencing, while a linear combination $\alpha^{\prime} \mathrm{X}(\mathrm{t})$ is stationary, $\mathrm{X}(\mathrm{t})$ is co-integrated with vector $\alpha$. Engle and Granger (Engle and Granger 1987) presented the modelling of co-integration for non-stationary time series variables $\mathrm{X}(\mathrm{t})$.

The co-integration test enables estimation of LT relationships for co-integrated variables from the time series variable. The co-integration test is practically applicable when the variables contain unit roots. The Johansen test is one of the most commonly used for testing co-integration in multivariate time series variables X(t) (Johansen, 1991). It allows several co-integrating relationships, hence more applicable than the Engle-Granger test, which is based on the Dickey-Fuller test for unit roots from a single estimated co-integrating relationship. The Johansen test is used to test the co-integrating relationship of the price of iron ore against the econometric variables and is carried out according to the following steps:

(1) VECM representation and extract the effects of the lagged time series variable using Frisch-Waugh-Lovell (FWL) theorem:

$$
\widehat{u}(\mathrm{t})=\Pi \widehat{v}(\mathrm{t})+\epsilon \mathrm{t}
$$

where $\Pi$ is the matrix of coefficients on the vector error correction term, $\hat{\mathrm{u}}(\mathrm{t})$ is the residual for $\Delta \mathrm{X}_{\mathrm{t}}$ from the lefthand side (LHS), $\widehat{v}(t)$ is the residual for $X_{t-1}$ right-hand side (RHS), and et is the stochastic disturbances (or error terms).

(2) All the variables in the co-integration are related symmetrically. No endogenous nor exogenous variables exist. This system is written as:where $(\tilde{\alpha})$ is the $\mathrm{k} \times \mathrm{k}$ matrix of intercept, a constant, $(\beta \sim)$ ' is the $\mathrm{k} \times \mathrm{k}$ matrix of the coefficients of the lags of $X_{t}, \tilde{U}(t)$ is the residual for $\Delta X_{t}$ from the left-hand side (LHS), and $\tilde{v}(\mathrm{t})$ is the residual for $\mathrm{X}_{\mathrm{t}-1}$ right-hand side (RHS).

$\frac{1}{(\tilde{\alpha})} u(t)=(\beta \sim)^{\prime} v(t)$

(3) The adjustment parameters $\alpha$ and the $\Phi *$ 's is estimated as:where $X_{t}$ is the time series variable, $\Phi$ is the $\mathrm{k} \times \mathrm{k}$ matrix, $\delta$ is the stationary error, et is the stochastic disturbances (or error terms), $\Phi$ is the $\mathrm{k} \times \mathrm{k}$ matrix, $\beta$ is the coefficient of the lags of $X_{t}$, and $\alpha$ is the intercept, a constant.

$$
\Delta \mathrm{X}(\mathrm{t})=\phi+\alpha \beta^{\prime} \mathrm{X}(\mathrm{t}-1)+\sum_{i=1}^{p-1} \Phi \mathrm{i} * \Delta \mathrm{X}(\mathrm{t}-\mathrm{i})+\epsilon \mathrm{t}
$$

There are two types of Johansen co-integration tests in VECM which are the trace test and the maximal 
eigenvalue test. In the Johansen co-integration test, the rank of the long-run impact matrix is equal to the number of co-integrating relationships. In this research, maximal eigenvalue test is applied which undergo two processes: (1) estimate the VECM model with and without trend, with and without constant, and with varying numbers, $\mathrm{k}$, of co-integrating vectors and (2) compare the models using likelihood ratio tests. The maximal eigenvalue test considers the null hypothesis that the co-integrating rank is $\mathrm{k}$ against the alternative hypothesis that the co-integrating rank is $\mathrm{k}+1$ and follows a non-standard distribution.

The trace test is carried out to assesses the null hypotheses $H(r)$ of co-integration rank ( $r$ ) less than or equal to $n$ (dimensions of the data) against the alternative $H(n)$. An example of the interpretation of Johansen co-integration result is summarized in Table 1.

It is also important to determine a reasonable lag when VECM is tested for co-integration. This process is automated in MATLAB software (MATLAB MathWorks, n.d.a) to limit the valid lags that are applied.

\section{Johansen co-integration test in bivariate model}

The time series bivariate model of the co-integration test allows interpretation and definition of relationship between the two variables when the variables are not stationary. In a bivariate model co-integration for the variables $y(t)$ and $x(t)$, the two variables are co-integrated or being individually stochastic and have a long-run equilibrium relationship. The purpose of bivariate modelling is to define the detailed co-integrating relation between respective variables and iron ore.

\section{Johansen co-integration test in multivariate model}

To test for co-integration in multivariate time series, the Johansen trace test can be used. The test was derived by Johansen (1991) and tests the null hypothesis at most $r$ co-integration relationships against the alternative that there are more than $r$ co-integration relationships in multivariate time series variables. The purpose of multivariate modelling is to investigate the general trend of the distribution of the test statistic on number of cointegrations against iron ore price, which will be able to observe the change in overall commodity market pricing system.

\section{Estimate VECM parameters for bivariate modelling using the Engle-Granger test}

Estimation of the VECM using the Engle-Granger test (Engle et al., 1987) is carried out between the natural logarithm values of iron ore prices against natural logarithm values of the other monthly commodity variables followed by the Johansen co-integration test if the variables are co-integrated. The estimation is simply done using MATLAB (MATLAB MathWorks, n.d.b). VECM parameters are estimated using the following equation to find out the influence of the variables to iron ore price and vice versa:

$\Delta X t=\alpha \beta^{\prime} * X(t-1)+\sum_{j=0}^{k-1} \Gamma j-X(t-j)+v+\delta t+e t$

where $\alpha$ is the coefficient matrix of the error correction term and the adjusted long run disequilibrium of the variables, $\beta$ is the coefficient matrix of the co-integrating vectors, $\Gamma j$ is the coefficient which estimates short-run shock effects on $\Delta x t, v$ is a constant term, $\delta t$ is the linear time trend term, and $e t$ is the normally distributed error term.

The coefficient $\prod$ which is $\alpha \beta^{\prime}$ has rank $r$ which can be written as the product:

$\prod(n x n)=\alpha(n x r) \beta^{\prime}(r x n)$

For a bivariate VAR(1) model, equation is written as below:

$\mathrm{Xt}=\prod(1) X(t-1)+e t$
Table 1 Example of interpretation of Johansen co-integration result

\begin{tabular}{llc}
\hline Co-integration rank $(r)$ tested & $h$-value & $\begin{array}{l}\text { Number } \\
\text { of co- } \\
\text { integra- } \\
\text { tions }\end{array}$ \\
\hline 0 and 1 & If $h=0$ for $r=0$ and $h=0$ for $r=1$ & 0 \\
If $h=1$ for $r=0$ and $h=0$ for $r=1$ & $\begin{array}{c}\text { Between } \\
0 \text { and } 1\end{array}$ \\
& If $h=0$ for $r=0$ and $h=1$ for $r=1$ & 1 \\
If $h=1$ for $r=0$ and $h=1$ for $r=1$ & 1 \\
\hline
\end{tabular}


Since $\mathrm{Xt}$ is co-integrated with one co-integrating vector rank $\left(\prod\right)=1$ and can be decomposed to:

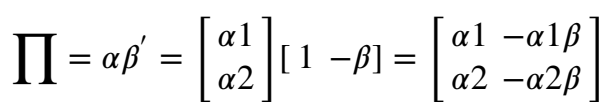

VECM equation by equation to show change in $X(1 t)$ and $X(2 t)$ written:

$\Delta X(1 t)=\alpha 1[X(1 t-1)-\beta \mathrm{X}(2 \mathrm{t}-1)]+e(1 t)$

$\Delta X(2 t)=\alpha 2[X(1 t-1)-\beta \mathrm{X}(2 \mathrm{t}-1)]+e(2 t)$

From Eqs. 10 and 11, the VECM parameters are estimated; the estimates which are of interest are the $\beta$ normalising co-integrating vector and $\alpha$ which is the speed of adjustment.

\section{Granger causality test}

Granger (1969) suggested a bivariate model for testing causality relationships in econometrics where a variable $\mathrm{Xt}$ is said to be Granger-causal variable for another time series variable Yt, if Xt helps to predict Yt. To test the Granger causality, it is required to estimate the following $2 \times 2$ unrestricted VAR models for iron ore prices and other commodity prices at levels.

$\Delta X t=\alpha 10+\sum_{k=1}^{p} \alpha 1 * k X(t-k)+\sum_{k=1}^{p} \alpha 2 * k Y(t-k)+e 1 t$

$\Delta Y t=\beta 10+\sum_{k=1}^{p} \beta 1 * k X(t-k)+\sum_{k=1}^{p} \beta 2 * k Y(t-k)+e 2 t$ where $X t$ represents iron ore prices and $Y t$ represents 12 other commodity prices; $e 1 t$ and $e 2 t$ are stochastic disturbances, i.e., error terms.

\section{Results and discussions}

\section{Augmented Dickey-Fuller (ADF) test results}

ADF outcome shows that the iron ore, gold, oil, silver, copper, Commodity Price Index (CPI), Australian coal, tin, LNG, aluminium, lead, nickel, and zinc all contain unit root at all lags between 0 and 6 months, at all models and at all test statistic, and hence the time series variables are non-stationary.

From the ADF test results shown in Table 2, it can be concluded that the null hypothesis (unit root exists) has been accepted (or cannot be rejected) at 5\% significance (or with $95 \%$ confidence interval) for all the time series variables (iron ore, gold, oil, silver, copper, Commodity Price Index (CPI), Australian coal, tin, LNG, aluminium, lead, nickel, and zinc). This means that all the time series variables have unit roots and is non-stationary. Therefore, an assumption is made throughout this research that iron ore, gold, oil, silver, copper, CPI, tin, LNG, aluminium, lead, nickel, and zinc price data contain unit root, are non-stationary, and can apply the Johansen co-integration test.

The reason why the non-stationary time series variable is a required condition to "Johansen co-integration" is because the Johansen co-integration assumes that the combination of co-integrated variables (or transformed state) produces the stationary system which consequently the variables may
Table $2 p$-value of ADF test for unit roots (at $5 \%$ significance).

\begin{tabular}{llllllll}
\hline Lags (months) & 0 & 1 & 2 & 3 & 4 & 5 & 6 \\
\hline Iron ore & 0.43 & 0.26 & 0.30 & 0.28 & 0.28 & 0.27 & 0.25 \\
Gold & 0.99 & 0.98 & 0.98 & 0.98 & 0.98 & 0.96 & 0.95 \\
Oil & 0.38 & 0.21 & 0.20 & 0.25 & 0.26 & 0.28 & 0.33 \\
Silver & 0.51 & 0.42 & 0.49 & 0.49 & 0.43 & 0.41 & 0.45 \\
LNG & 0.13 & 0.12 & 0.14 & 0.13 & 0.13 & 0.18 & 0.16 \\
Aluminium & 0.46 & 0.40 & 0.40 & 0.34 & 0.27 & 0.33 & 0.42 \\
Copper & 0.54 & 0.42 & 0.42 & 0.43 & 0.44 & 0.44 & 0.49 \\
CPI & 0.56 & 0.45 & 0.44 & 0.43 & 0.39 & 0.39 & 0.44 \\
Tin & 0.58 & 0.49 & 0.43 & 0.45 & 0.46 & 0.50 & 0.49 \\
Lead & 0.50 & 0.39 & 0.45 & 0.42 & 0.40 & 0.38 & 0.37 \\
Nickel & 0.34 & 0.17 & 0.19 & 0.25 & 0.23 & 0.20 & 0.20 \\
Zinc & 0.42 & 0.33 & 0.38 & 0.39 & 0.37 & 0.37 & 0.32 \\
\hline
\end{tabular}


have a long-term relationship. In other words, the process involves transformation from non-stationary to stationary.

\section{Johansen co-integration test results}

\section{Johansen co-integration test in bivariate model for commodity price or index against iron ore price (monthly)}

This test finds out whether co-integration exists between commodity price and index against iron ore price. $\mathrm{h}=0$ means there exists no co-integrating relationship and $\mathrm{h}=1$ shows there exists co-integrating relationship between each commodity prices and index against iron ore price. The results are interpreted in accordance with the "Johansen cointegration test results" section and Appendix 1 Fig. 2 is showing number of co-integrations (from 0 to 1 ) for different commodities and index for each lag out of 0 to 45 different lags against iron ore.

The test rejects a null hypothesis for co-integration if $\mathrm{h}=1$ and fails to reject null hypothesis for co-integration if $\mathrm{h}=0$. According to the result in Table 3 , it shows that null hypothesis has been rejected for co-integration against iron ore price for $5 \%$ significance between lag 0 and 45 in the following order: LNG - aluminium - nickel - Australian coal - zinc - CPI - oil - silver - tin - copper - lead - gold. Overall, co-integration is greatest between lag of 1 and 10 months, then gradually decreases until lag of 20 months and increases again at lag of 32 months then maintain its level until 45 months.

Table 3 Number of co-integration options between commodity prices against iron ore prices

\begin{tabular}{llll}
\hline Commodity prices & $\begin{array}{l}\text { No co- } \\
\text { integration }\end{array}$ & $\begin{array}{l}\text { Between zero and } \\
\text { one co-integration }\end{array}$ & $\begin{array}{l}\text { One } \\
\text { co-inte- } \\
\text { gration }\end{array}$ \\
\hline Aluminium & 0 & 1 & 45 \\
Copper & 32 & 14 & 0 \\
CPI & 27 & 13 & 6 \\
Gold & 42 & 4 & 0 \\
Lead & 39 & 7 & 0 \\
LNG & 2 & 3 & 41 \\
Nickel & 13 & 11 & 22 \\
Oil & 31 & 10 & 5 \\
Silver & 20 & 22 & 4 \\
Tin & 26 & 20 & 0 \\
Zinc & 32 & 5 & 9 \\
Australian coal & 26 & 9 & 11 \\
\hline
\end{tabular}

The findings from bivariate analysis using Johansen cointegration are as follows:

- Aluminium and LNG-co-integration exists at almost all lags

- Copper - co-integration exists until lag of 10-14 months

- Silver, tin, zinc, and Australian coal-co-integration exists up to 10 months of lag, tendency of no co-integration exists between 10 and 20, then co-integration exists again at 25-30 months lag until 40 months lag

- Oil and CPI-co-integration only exists from lag 0 to 10 months, then diminishes after 10 months

- Lead and gold—almost no co-integrations exist

Detailed relationship between iron ore and 12 commodity prices/index can be determined by VECM bivariate modelling in the "Estimate VECM parameters for bivariate modelling using Engle-Granger test results" section.

\section{Johansen co-integration test in multivariate model amongst 12 different commodity prices and index as well as iron ore prices (monthly)}

Johansen co-integration in the multivariate model was tested for co-integration amongst 12 monthly commodity prices and index as well as iron ore price to observe how many co-integrations exist. Different lags were tested to visualize trend of number of co-integrations in each lag and to observe the overall relationship between commodity prices and index against iron ore prices. Since there are 13 different commodity prices (n), there are 12 possible ranks (r). Number of ranks ( $r$ ) in other words is the number of co-integrations.

The rank of the VAR model starts with 4 at lag 0 meaning that there are 4 relationships amongst 12 different commodity prices and index as well as iron ore prices (i.e., 4 relationships within 13 different commodity prices). The rank changes to 6 at 1 month, gradually decreases to 2 ranks until 8 months lag, maintains 2 until 11 months lag, gradually increases to 10 until 20 months, maintains 10 until 27 months, and then gradually decreases between 1 and 2 ranks until 45 months. The trend and results are shown in Fig. 1.

From Fig. 1, the cyclic effect is exhibited which enabled wider understanding of commodity pricing system where:

- There are 3 commodities which continuously cointegrates with iron ore price change at all lags until 27 months,

- It takes between 20 and 27 months for at least 10 commodities to show a similar trend when change (increase or decrease) has been applied to iron ore price and 12 other commodity prices and index, and 
Fig. 1 Number of co-integrations $(\mathrm{N})$ against number of lag months (L) for multivariate model co-integration amongst

12 monthly commodity prices

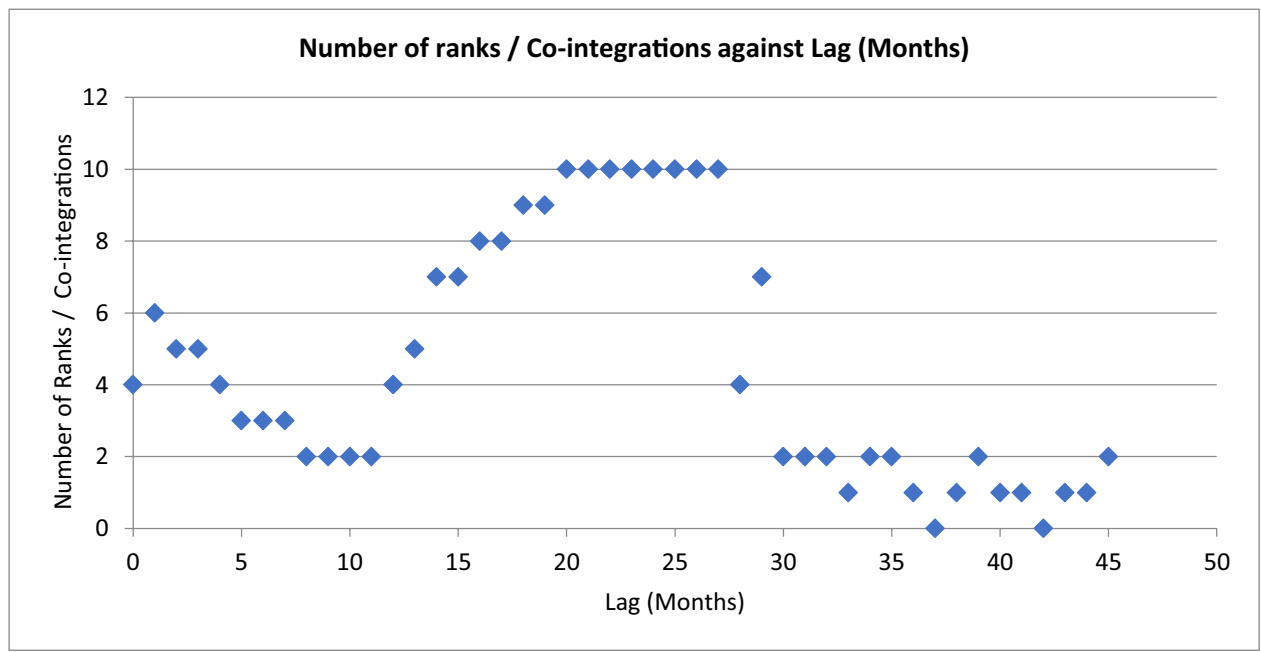

- The change in the commodity pricing system today diminishes after 30 months.

The trend-line can be drawn from Fig. 1 which shows strong resemblance to a sine curve and the approximate equation of the curve is shown in the equation below: positive for VECM to be statistically significant-indicates positive association,

$\beta 1$ is the normalising beta value which is the \% appreciated per iron ore prices per $1 \%$ increase in commodity prices.

Numberofco - integrations $(N)=8 \sin \left[\frac{\pi}{15}(L-10)\right]+2[$ whererange $0 \leq L \leq 45]$

where $N$ is the number of co-integrations and $L$ is the number of lag months.

\section{Estimate VECM parameters for bivariate modelling using Engle-Granger test results}

Johansen co-integration using bivariate modelling can be further assessed using vector error correction modelling using the Engle-Granger test to determine the relationship between different commodity prices against iron ore price. To determine whether VECM is statistically significant and stable long-term relationship, we need $\alpha 1<0$ or $=0, \alpha 2>0$ or $=0$ and at least one of them cannot be equal 0 . The outcome of VECM parameters is largely $\alpha$-long-term disequilibrium matrix and $\beta$-normalising co-integrating vector. The $\alpha$ and $\beta$ are the $1 \times 2$ matrix and its interpretation is carried out as: $\alpha=(\alpha 1, \alpha 2)$ and $\beta=(1,-\beta 1)$.where.

$\alpha 1$ is the adjustment coefficient which indicates how quickly the system comes to equilibrium, must be negative for VECM to be statistically significant,

$\alpha 2$ is the adjustment coefficient which indicates how quickly the system comes to equilibrium, must be
VEC modelling of iron ore prices to all other commodity prices and index is defined statistically significant with stable long-term relationship because all $\alpha 1<0$ and $\alpha 2>0$ which have been shown in Appendix 2 Table 6. It also shows results including $\alpha 1, \alpha 2, \beta 1$, and whether positive or negative association exists between iron ore prices and commodity prices.

From the VEC model estimation, oil, Australian coal, and copper were the commodities with $p$-value $<0.05$; this indicates that null hypothesis is rejected; hence, the VEC model coefficients are significant for oil, Australian coal, and copper. Long-run disequilibrium adjustment matrix was obtained for oil $\alpha$ (i.e., $\alpha 1$ and $\alpha 2)=(-0.0360,0.0374)$, Australian coal $\alpha$ (i.e., $\alpha 1$ and $\alpha 2)=(-0.0133 ; 0.0479)$, and copper $\alpha$ (i.e., $\alpha 1$ and $\alpha 2)=(-0.0653 ; 0.3122)$ with $p$-values for $\alpha 1$ and $\alpha 2$ (0.0305; 0.0093), (0.0350; 0.0232), and (0.0411, $0.0287)$, respectively. High $p$-values $(>0.05)$ for other commodities, gold, silver, LNG, aluminium, CPI, tin, lead, nickel, and zinc indicate that the VEC model coefficients are insignificant, and that null hypothesis cannot be rejected.

The normalising co-integrating vector $\beta 1=-1.3415$ shows that a $1 \%$ increase in the oil price leads to an appreciation of iron ore price by approximately $1.34 \%, 1 \%$ increase 
Table 4 Granger causality test result-iron ore to copper, Australian coal, and oil

\begin{tabular}{|c|c|c|c|c|c|c|c|c|c|}
\hline \multirow[b]{2}{*}{ Lag } & \multicolumn{3}{|c|}{ Iron ore $\longrightarrow>$ copper } & \multicolumn{3}{|c|}{ Iron ore $\longrightarrow>$ Australian coal } & \multicolumn{3}{|c|}{ Iron ore $->$ oil } \\
\hline & $p$-value & Stat & $c$-value & $p$-value & Stat & $c$-value & $p$-value & Stat & $c$-value \\
\hline 0 & 1 & 0 & $\sim 0$ & 1 & 0 & $\sim 0$ & 1 & 0 & $\sim 0$ \\
\hline 1 & 0.7161 & 0.1322 & 3.8415 & $\sim 0$ & 22.1702 & 3.8415 & $\sim 0$ & 13.848 & 3.8415 \\
\hline 2 & 0.5052 & 1.3656 & 5.9915 & $\sim 0$ & 34.7015 & 5.9915 & $\sim 0$ & 16.6379 & 5.9915 \\
\hline 12 & 0.0077 & 26.9925 & 21.0261 & $\sim 0$ & 71.1825 & 21.0261 & $\sim 0$ & 50.5978 & 21.0261 \\
\hline 18 & $\sim 0$ & 46.1784 & 28.8693 & $\sim 0$ & 82.8847 & 28.8693 & $\sim 0$ & 66.8899 & 28.8693 \\
\hline
\end{tabular}

\begin{tabular}{|c|c|c|c|c|c|c|c|c|c|}
\hline \multirow[b]{2}{*}{ Lag } & \multicolumn{3}{|c|}{ Copper $\rightarrow>$ iron ore } & \multicolumn{3}{|c|}{ Australian coal $\longrightarrow$ iron ore } & \multicolumn{3}{|c|}{ Oil $\longrightarrow>$ iron ore } \\
\hline & $p$-value & Stat & $c$-value & $p$-value & Stat & $c$-value & $p$-value & Stat & $c$-value \\
\hline 0 & 1 & 0 & $\sim 0$ & 1 & 0 & $\sim 0$ & 1 & 0 & $\sim 0$ \\
\hline 1 & $\sim 0$ & 10.8205 & 3.8415 & 0.1753 & 1.8374 & 3.8415 & 0.9902 & $\sim 0$ & 3.8415 \\
\hline 2 & $\sim 0$ & 25.5442 & 5.9915 & $\sim 0$ & 14.3388 & 5.9915 & 0.007 & 9.9194 & 5.9915 \\
\hline 12 & $\sim 0$ & 50.7066 & 21.0261 & $\sim 0$ & 45.6003 & 21.0261 & $\sim 0$ & 33.7044 & 21.0261 \\
\hline 18 & $\sim 0$ & 60.8218 & 28.8693 & $\sim 0$ & 45.6696 & 28.8693 & $\sim 0$ & 34.8793 & 28.8693 \\
\hline
\end{tabular}

Table 5 Granger causality test result-copper, Australian coal, and oil to iron ore

\section{Discussion}

in the Australia coal price leads to appreciation of iron ore price by approximately $1.29 \%$, and finally $1 \%$ increase in the copper price leads to an appreciation of iron ore price by approximately $0.017 \%$ that are significant and meaningful.

The speed of adjustment parameters for oil price is -0.036 ( $p$-value 0.0305 ) meaning approximately $3.6 \%$ of oil price change per month can be attributed to the disequilibrium between actual and equilibrium levels and 0.0374 ( $p$-value 0.0093 ) shows that the variability of iron ore price induces a positive change in the oil price. The same principle applies to coal price and copper, where approximately $1.33 \%$ of oil price and $6.53 \%$ of copper price per month can be attributed to the disequilibrium between actual and equilibrium levels and the variability of iron ore price induces a positive change in both the coal price and copper price.

\section{Granger causality test results}

The Granger causality test is carried out to test bi-directional causality test performed between iron ore prices and copper and oil and coal prices, and the results are tabulated in Tables 4 and 5. Results indicate that there was no causality found when no lag was applied; in other words, null hypothesis for Granger causality is not rejected at lag of 0 month. However, from lag of 1 month, there is bi-directional causality between iron ore prices and copper and coal prices, meaning null hypothesis for Granger causality is rejected from lag of 1 month. Iron ore always showed Granger cause to oil when tested with lag of 1 month onwards; however, oil did not have Granger cause at lag of 1 and 2 months and Granger cause occurs when tested from 12 months onwards.
The iron ore prices have changed vastly in past 30 years as shown in Appendix 3 Fig. 3. In March 1990, the price of iron ore was only US\$37.50 per tonne, and in December 2004, it was US\$37.90 per tonne. However, between January 2005 and March 2008, the price had risen to US\$197.12 per tonne. Then, until April 2009, the price had dramatically dropped to $\$ 59.78$ per tonne, which was notably during the Global Financial Crisis (GFC) period. The price drop during GFC is followed by prompt recovery to $\$ 187.18$ in February 2011. After that, there were notable fluctuations in the price until December 2013, then sharp decline from January 2014 until December 2015 to $\$ 40.50$ per tonne. From January 2016 to April 2020 , the iron ore price had fluctuated considerably, but had shown a tendency to increase overall.

Based on Granger causality and VECM, it is certain that oil, copper, and coal are interlinked with consumption of iron ore including steel production as well as production of other industrial metals, although it is uncertain to define the reason behind the bi-directional Granger causes between them. For instance, Australian thermal coal is highly used across the Asia-Pacific region for power generation purpose even today, which is then used to produce steel and oil is used to consume steel manufactured products such as automobiles, ships, and aircrafts. Until reliance on coal-powered plant and fossil fuel would reduce at significant level, this relationship would continue. There are continuous efforts to date to minimise the use of thermal coal and oil, and hence 
this relationship could potentially change in foreseeable future. Copper is the second highest produced and used base metal after aluminium (LePan, 2020), which is widely used as a power cable. The relationship of power generation, energy production, and consumption seems to play a part in demand of copper, although aluminium is the highest produced and used base metal; it did not have much relevance to iron ore price and does not have much relevance to power generation, energy production, and consumption process. This would hence lead to the relationship, if iron ore price or Australian coal price or copper price increases, oil price will start increasing within 1 month. Vice versa is also true for Australian coal price or copper price.

\section{Conclusions}

This research has investigated the relationship between the iron ore price against 12 different monthly commodity prices and index by application of the Johansen co-integration test in bivariate model. Multivariate Johansen co-integration was utilized to determine the co-integrating relationship between 12 different monthly commodity prices and index against iron ore price. Thirty years data (over period 1990-2020) were utilized to investigate the effect with lag month varying from 0 to 45 months. Based on ADF test results, conclusion is made that all the time series commodity prices and index have unit roots and is non-stationary, and hence Johansen co-integration test can be applied.

Both bivariate and multivariate Johansen co-integration tests revealed the co-integrating relationship at $95 \%$ confidence interval which confirmed that there is a long-term relationship between iron ore prices against 12 different monthly commodity prices and index.

The trend-line from a multivariate modelling displays number of co-integrations that resembles a sine curve and its equation is shown in Eq. 7. The sine curve interprets that there are 3 commodities which continuously co-integrates with iron ore price change at all lags until 27 months. This hence means that when an impact to commodity price(s) has been observed, it will take at least 20 and up to 27 months to visualize the change to entire commodity market.

VECM estimation has revealed in favour of short-run responses to a long-term relationship between iron ore prices and oil, Australian coal, and copper prices over the period 1990-2020. The normalising vector $\beta 1$ reveals that a $1 \%$ increase in the oil, Australian coal, and copper price leads to an appreciation of iron ore price by approximately $1.34 \%$, $1.29 \%$, and $0.017 \%$, respectively. The speed of adjustment parameter $\alpha 1$ which represents approximately $3.6 \%$ of oil price, $1.33 \%$ of Australian coal price, and $6.53 \%$ of copper price change per month attributes to the disequilibrium between actual and equilibrium levels. Positive adjustment coefficient $\alpha 2$ indicates that the change in iron ore prices induces a positive change in oil, Australian coal price, and copper price which are $0.0374,0.0479$, and 0.3122 , respectively.

The Granger causality test results indicate that there is no causality found at zero (no) lag; however, from lag of 1 month onwards, there is bi-directional causality between iron ore price and copper and coal prices. Oil price does not show Granger cause on iron ore price until lag of 12 months, whereas iron ore price has Granger cause on oil price from lag of 1 month onwards. Therefore, Granger causality result aligns with the multivariate co-integration results which indicate that 3 commodities co-integrate with iron ore price at all lags and it is found that these are oil, copper, and Australian coal.

According to the results, it has been revealed that it will be more accurate to consider prolonged period data for taking better-informed decisions to find the relationships and their consequent strength of association. This is due to the limitation with shorter periods, wherein data loss inhibits the information variability and consequently compromises improved accuracy of results. Therefore, in the present study, approximately 30 years of data was considered. As a result, more accurate relationships have been established. The results and associated information are important for the iron ore mining companies across the world when setting their portfolio amongst different commodities, and for the commodity investors. This is because maintaining optimum ratio between different commodities is paramount to maximise NPV for its operations and to minimise any risk of NPV loss due to commodity price downturn for mining companies and investors.

This research has given an insight into the relationship between the iron ore price against oil, copper, and Australian coal price based on Granger causality and VECM results. Granger causality and VECM results indicate that oil, copper, and coal are interlinked with consumption of iron ore including steel production as well as production of other industrial metals. In other words, it is closely linked with energy lifecycle associated with iron ore to steel production. Thermal coal is used to generate power, copper is used for power cables, power is used at iron ore plants, steel mills produce steel using iron ore, and oil is then used to operate steel manufactured products such as mechanical equipment, automotive, and aerospace. Future research should involve economic analysis to determine the economic reason behind the bi-directional Granger causes between iron ore, coal, copper, and oil. 


\section{Appendix 1}

Fig. 2 Co-integration between commodity prices against iron ore prices for different lags

\section{Cointergration between commodity prices againts iron ore prices for different lags}

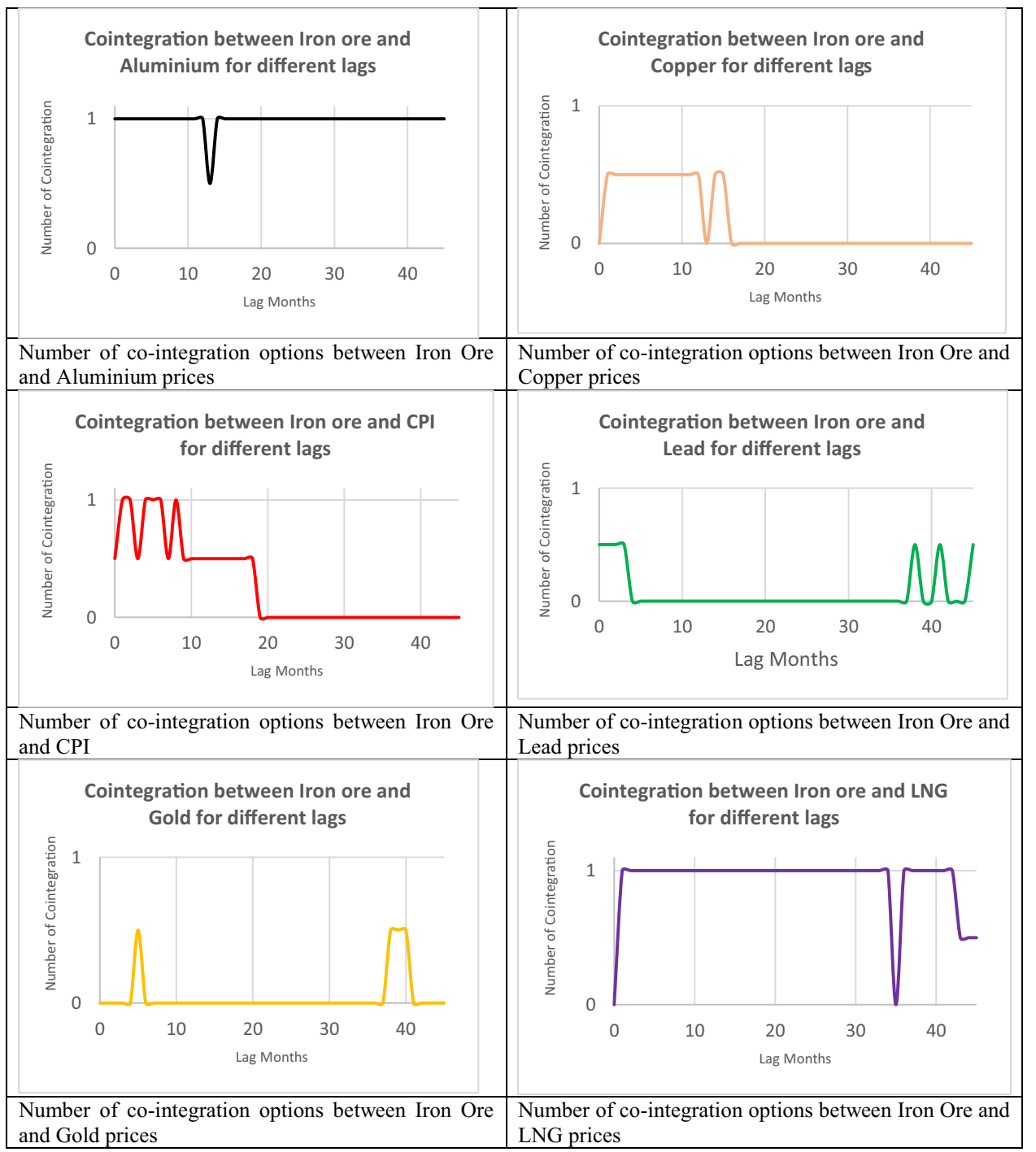


Fig. 2 (continued)

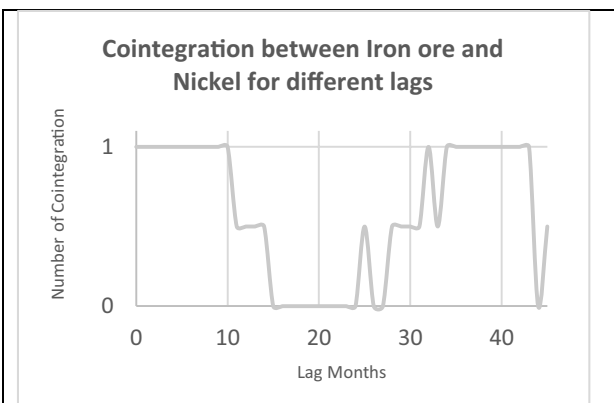

Number of co-integration options between Iron Ore and Nickel prices

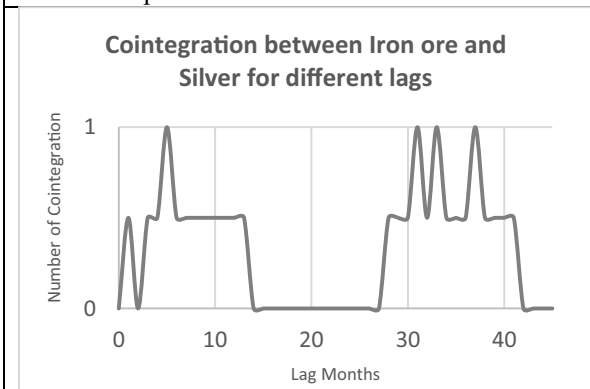

Cointegration between Iron ore and Oil for different lags

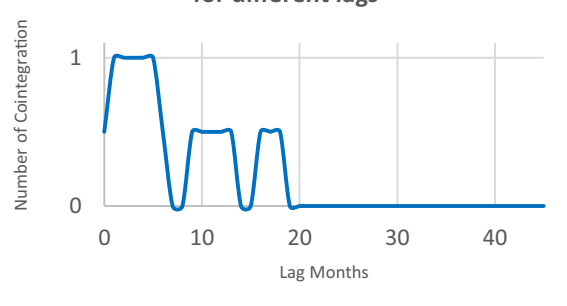

Number of co-integration options between Iron Ore and Oil prices

Cointegration between Iron ore and Tin for different lags

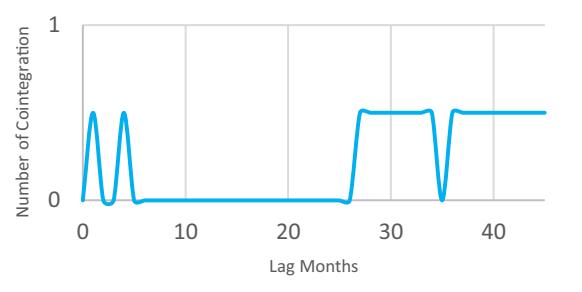




\section{Appendix 2}

Table 6 VECM estimation results (at 5\% significance)

\begin{tabular}{|c|c|c|c|c|c|c|}
\hline Commodity price types & $\alpha=(\alpha 1, \alpha 2)$ & $p$-value & $c$-value & Stat & $\beta 1$ & $\begin{array}{l}+ \text { or- } \\
\text { associa- } \\
\text { tion }\end{array}$ \\
\hline Gold & $(-0.0307,0.0963)$ & $(0.4474,0.4080)$ & $\begin{array}{l}(-3.3542 \\
-20.2414)\end{array}$ & $\begin{array}{l}(-2.1671 \\
-10.1191)\end{array}$ & -0.0733 & + \\
\hline Oil* & $\begin{array}{l}(-0.0360 \\
0.0374)\end{array}$ & $(0.0305,0.0093)$ & $\begin{array}{l}(-3.3541 \\
-20.2430)\end{array}$ & $\begin{array}{l}(-3.5451 \\
-28.0309)\end{array}$ & -1.3415 & + \\
\hline Silver & $\begin{array}{l}(-0.0423 \\
0.0038)\end{array}$ & $(0.085,0.0632)$ & $\begin{array}{l}(-3.3541 \\
-20.243)\end{array}$ & $\begin{array}{l}(-3.1307 \\
-19.1282)\end{array}$ & -4.5795 & + \\
\hline LNG & $\begin{array}{l}(-0.0179 \\
0.0006)\end{array}$ & $(0.5152,0.5237)$ & $\begin{array}{l}(-3.3541 \\
-20.243)\end{array}$ & $\begin{array}{l}(-2.0192 \\
-8.3484)\end{array}$ & -8.3270 & + \\
\hline Aluminium & $(-0.0339,0.1243)$ & $(0.2425,0.1700)$ & $\begin{array}{l}(-3.3541 \\
-20.243)\end{array}$ & $(0.24250 .1700)$ & -0.0791 & + \\
\hline Copper* & $(-0.0653,0.3122)$ & $\begin{array}{l}(0.0411, \\
0.0287)\end{array}$ & $\begin{array}{l}(-3.3541 \\
-20.243)\end{array}$ & $\begin{array}{l}(-3.4321 \\
-22.8517)\end{array}$ & -0.0168 & + \\
\hline CPI & $\begin{array}{c}(-0.0816 \\
-0.0116)\end{array}$ & $(0.0739,0.0519)$ & $\begin{array}{l}(-3.3541 \\
-20.243)\end{array}$ & $\begin{array}{l}(-3.1922 \\
-20.0715)\end{array}$ & -1.5512 & + \\
\hline Tin & $\begin{array}{l}(-0.0345 \\
2.1562)\end{array}$ & $(0.1800,0.1453)$ & $\begin{array}{l}(-3.3541 \\
-20.243)\end{array}$ & $\begin{array}{l}(-2.7647 \\
-14.9951)\end{array}$ & -0.0054 & + \\
\hline Lead & $\begin{array}{l}(-0.0650 \\
-0.3650)\end{array}$ & 0.06660 .0494 & $\begin{array}{l}(-3.3541 \\
-20.243)\end{array}$ & $\begin{array}{l}(-3.2364 \\
-20.3042)\end{array}$ & -0.0490 & + \\
\hline Australian coal* & $\begin{array}{l}(-0.0133 \\
0.0479)\end{array}$ & 0.03500 .0232 & $\begin{array}{l}(-3.3541 \\
-20.243)\end{array}$ & $\begin{array}{l}(-3.4928 \\
-23.844)\end{array}$ & -1.2858 & + \\
\hline Nickel & $\begin{array}{l}(-0.0556 \\
-1.131)\end{array}$ & 0.33290 .3102 & $\begin{array}{l}(-3.3541 \\
-20.243)\end{array}$ & $\begin{array}{l}(-2.4164 \\
-11.6177)\end{array}$ & -0.0043 & + \\
\hline Zinc & $\begin{array}{l}(-0.0369 \\
-0.1908)\end{array}$ & 0.44030 .4856 & $\begin{array}{l}(-3.3541 \\
-20.243)\end{array}$ & $\begin{array}{l}(-2.1825 \\
-8.9329)\end{array}$ & -0.0350 & + \\
\hline
\end{tabular}

${ }^{*} p$-value $<0.05$

\section{Appendix 3}

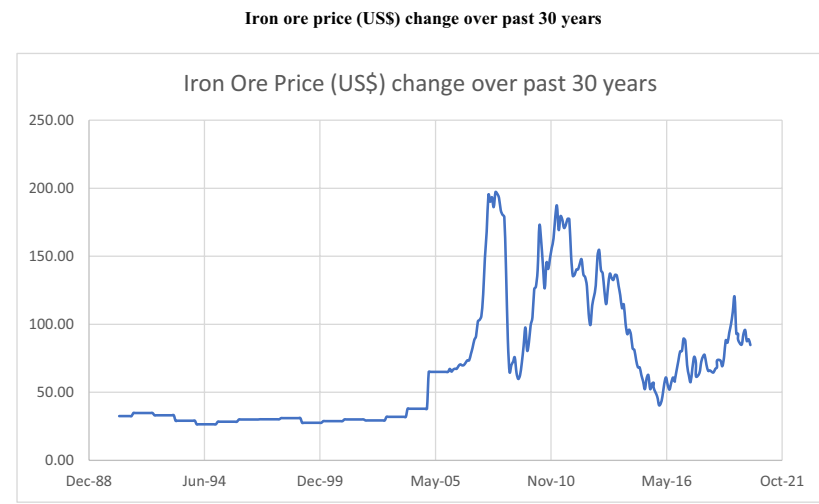

Fig. 3 Iron ore price (US\$) change over past 30 years
Author contribution Mr Yoochan Kim contributed to the study's conceptualization and conducted study design, data collection, and writing of the manuscript. Dr Apurna Ghosh and Professor Erkan Topal participated in the supervision, guidance of the research methodology, and revision of the paper. Dr Ping Chang has helped in reviewing and editing.

Funding Open Access funding enabled and organized by CAUL and its Member Institutions. The authors thank Curtin University for providing fund to conduct this research.

\section{Declarations}

Conflict of interest The authors declare no competing interests.

Open Access This article is licensed under a Creative Commons Attribution 4.0 International License, which permits use, sharing, adaptation, distribution and reproduction in any medium or format, as long as you give appropriate credit to the original author(s) and the source, provide a link to the Creative Commons licence, and indicate if changes were made. The images or other third party material in this article are included in the article's Creative Commons licence, unless indicated 
otherwise in a credit line to the material. If material is not included in the article's Creative Commons licence and your intended use is not permitted by statutory regulation or exceeds the permitted use, you will need to obtain permission directly from the copyright holder. To view a copy of this licence, visit http://creativecommons.org/licenses/by/4.0/.

\section{References}

Caputo M, Robinson T and Wang H (2013) The relationship between bulk commodity and Chinese steel prices. Reserve Bank of Australia Bulletin September Quarter 2013, https://www.rba.gov.au/ publications/bulletin/2013/sep/pdf/bu-0913-2.pdf. Accessed 14 December 2019

Dickey DA, Fuller WA (1979) Distribution of the estimators for autoregressive time series with a unit root. J Am Stat Assoc 74(366):427-431. https://doi.org/10.2307/2286348.Accessed 11 January 2020

Engle R, Granger G (1987) Co-integration and error correction: representation, estimation and testing. J Econometrica 55(2):251-276. https://doi.org/10.2307/1913236.Accessed 14 December 2019

Estimate VEC model parameters. MATLAB MathWorks, https://au. mathworks.com/help/econ/estimate-vec-model-parameters.html. Accessed 2 February

Fu Z, Topal E and Erten O (2014) Optimisation of a mixed truck fleet schedule through a MIP model considering a new truck-purchase option. IMMM Transactions Section A, Mining Technology Vol 123, No 1, pp. 30-35https://www.tandfonline.com/doi/full/https:// doi.org/10.1179/1743286314Y.0000000055 Accessed 8 November 2021

Granger, C. W. J. (1969) Investigating causal relations by econometric models and cross-spectral methods. Econometrica, 37, 424-438, https://www.scirp.org/(S(i43dyn45teexjx455qlt3d2q))/reference/ ReferencesPapers.aspx?ReferenceID $=1202880$ Accessed 15 December 2021

Granger CWJ (1981) Some properties of time series data and their use in econometric model specification. Journal of Econometrica 16(1):121-130. https://doi.org/10.1016/0304-4076(81)900798Accessed14December2019

Granger C W J and Weiss A A (1983) Time series analysis of error-correcting models. Journal of Studies in Econometrics. Time Series and Multivariate Statistics, pp 255-278, https://doi.org/10.1016/ B978-0-12-398750-1.50018-8 . Accessed 14 December 2019

Haque MD, Topal E, Lilford E (2016) Relationship between the iron ore price and the Australian dollar-US-dollar exchange rate. Miner Econ 28(1):65-78. https://doi.org/10.1179/1743286315Y.00000 00008. Accessed 14 December 2019
Indexmundi commodity prices for coal, iron ore, oil, gold, CPI, silver, LNG, aluminium, copper, tin, lead, nickel, uranium and zinc, https://www.indexmundi.com/commodities/, Accessed 26 April 2020

Johansen S (1991) Estimation and hypothesis testing of co-integration vectors in Gaussian vector autoregressive models. Journal of Econometrica 59(6):1551-1580. https://doi.org/10.2307/29382 78. Accessed 14 December 2019

Johansen co-integration test. MATLAB MathWorks, https://au.mathw orks.com/help/econ/jcitest.html. Accessed 28 April 2020

LePan N (2020) Visual capitalist, all the world's metals and minerals in one visualization, https://www.visualcapitalist.com/all-theworlds-metals-and-minerals-in-one-visualization/ Accessed 25 November 2021

Ma Y, Wang J (2019) Co-movement between oil, gas, coal, and iron ore prices, the Australian dollars, and the Chinese RMB exchange rates: a copula approach. Resour Policy 63:101471. https://doi. org/10.1016/j.resourpol.2019.101471,Accessed15-Oct-2021

Observatory of Economic Complexity (OEC) - Iron Ore - https://oec. world/en/profile/hs92/iron-ore, Accessed 15 October 2021

Pustov A, Malanichev A, Khobotilov I (2013) Long-term iron ore price modelling: marginal costs vs incentive price. Resour Policy 38(4):558-567. https://doi.org/10.1016/j.resourpol.2013.09.003, Accessed 15-Oct-2021

Topal E (2008) Evaluation of a mining project using discounted cash flow analysis, decision tree analysis, Monte Carlo simulation and real option using an example, International Journal of Mining and Mineral Engineering, Vol. 1, No.1 pp. 62 - 76. http://www.inder science.com/offer.php?id=20457 Accessed 8 November 2021

Torres N, Afonso O, Soares I (2012), Oil abundance and economic growth-a panel data analysis, The Energy Journal, Vol. 33, No. 2 , pp. 119-148. https://www.jstor.org/stable/23268080 Accessed 9 November 2021

Warell L (2018) An analysis of iron ore prices during the latest commodity boom. Miner Econ 31:203-216. https://doi.org/10.1007/ s13563-018-0150-2. Accessed 15-Oct-2021

Wilson JD (2017) The political economy of conflict and cooperation, International Resource Politics in the Asia-Pacific. Chap 7:143-166. https://doi.org/10.4337/9781786438478, Accessed 15 October 2021

Publisher's note Springer Nature remains neutral with regard to jurisdictional claims in published maps and institutional affiliations. 